\title{
Central Bank Communication and Exchange Rate Volatility: A GARCH Analysis
}

\author{
Radovan Fišer \\ Institute of Economic Studies, Charles University, Prague \\ Roman Horváth* \\ Czech National Bank \\ and Institute of Economic Studies, Charles University, Prague
}

\begin{abstract}
We examine the effects of the Czech National Bank communication, macroeconomic news and interest rate differential on exchange rate volatility using generalized autoregressive conditional heteroscedasticity model. Our results suggest that central bank communication has a calming effect on exchange rate volatility. The timing of central bank communication seems to matter, too, as financial markets respond more to the communication before the policy meetings than after them. Next, macroeconomic news releases are found to reduce exchange rate volatility, while interest rate differential seems to increase it.
\end{abstract}

Keywords: central bank communication, exchange rate, GARCH.

JEL Classification: E52, E58, F31.

\footnotetext{
* We thank Tomas Holub and Filip Pertold for helpful comments. The views expressed in this paper are not necessarily those of the Czech National Bank. E-mail contacts: roman.horvath@.cnb.cz or roman.horvath@gmail.com
} 


\section{Introduction}

A considerable effort has been spent in last one or two decades to improve monetary policy transparency and to provide a clear communication of monetary policy actions in order to manage inflation expectations effectively. While the authoritative survey on central bank communication by Blinder et al. (2008) documents that the effects of central bank communication on financial markets were examined in many developed countries, but the evidence on emerging market economies is rather scant. ${ }^{1}$

In this paper, we aim to bridge this gap and study the impact of central bank communication on exchange rate volatility in one of small open emerging economies, the Czech Republic. ${ }^{2}$ We choose the exchange rate market, as this market is often of much larger importance than other segments of financial markets for the economic fluctuations in emerging economies. More specifically, we are interested how the releases of oral and written policy statements by the central bank (controlling for macroeconomic news and other factors) influence the exchange rate volatility using generalized autoregressive conditional heteroscedasticity (GARCH) model. Additional hypothesis that we want to address in this short policy paper is whether the timing of central bank communication matters, i.e. whether the financial markets respond to the communication more strongly before the monetary policy meetings than after them (see Ehrmann and Fratscher, 2007).

The paper is organized as follows. Section 2 introduces our empirical methodology and data. Section 3 presents the results. Concluding remarks follow. 


\section{Data and Empirical Methodology}

We use daily data from $3^{\text {rd }}$ January 2005 to $14^{\text {th }}$ February 2007, which makes 536 observations. The use of daily data is justified, if the main interest is to investigate the effectiveness of central bank communication (Jansen and de Haan, 2005) as well as by the recent evidence suggesting that it may takes several days until news are fully absorbed by financial markets (Evans and Lyons, 2005). The source of central bank communication and macroeconomic news variables is Reuters. Daily exchange rate and interest rate data are taken from the Czech National Bank (CNB).

Our baseline specification is a $\operatorname{GARCH}(1,1)^{3}$ process for exchange rate returns,

$$
\begin{gathered}
\Delta s_{t}=\mu+\xi_{t}, \\
\sigma_{t}^{2}=\gamma_{1}+\gamma_{2} \xi_{t-1}^{2}+\gamma_{3} \sigma_{t-1}^{2}+\phi_{i} \sum_{i=1}^{n} C B_{i t}+\rho_{1} n e w s_{t}+\rho_{2} \text { intdiff }_{t}+\omega_{j t},
\end{gathered}
$$

$s_{t}$ denotes the $\log$ of CZK/EUR. ${ }^{4}$ The constant term in equation (1), $\mu$, shows the average rate of appreciation or depreciation. The error term, $\xi_{t}$, of the mean equation (1) is assumed to have a conditional variance, $\sigma_{t}^{2}$, specified by (2). The conditional variance equation includes in addition to the constant, $\gamma_{1}, \mathrm{ARCH}$ term, $\xi_{t-1}$, and GARCH term, $\sigma_{t-1}^{2}$, the variables capturing the effect of central bank communication, $C B_{i t}$, macroeconomic news, news , and interest rate differential, intdiff .

We use the following variables to assess the effect of central bank communication: comment $_{t}$ - dummy variable that takes a value of unity on days, when a member of Czech National Bank Board commented verbally on the price stability, economic outlook, interest 
rates or exchange rate. The Board comprises of seven members, all with equal weight in monetary policy rate setting process. The governor has a casting vote in case, when some members are missing at the monetary policy meeting and their number is even. ${ }^{5}$ timing $_{t}$ - is defined as the product of comment $t$ and variable $\Gamma$, which is a categorical variable and takes value of 30 on the day of monetary policy meeting, 29 on the day before the meeting, 28 on two days before the meeting and so on. In consequence, comments closer to monetary policy meeting get greater weight.

minutes $_{t}$ - is a dummy variable with unitary value on the day, when monetary policy minutes are published (this is typically 12 days after monetary policy meeting).

It follows from the definition of our variables capturing the central bank communication that we focus on whether the central bank talked to the markets the rather than on interpreting the content of its communication. Therefore, the central bank communication variables are included only in the variance equation and exchange rate is assumed to follow random walk.

Macroeconomic news, news, is a dummy variable that takes a value of unity on days, in which scheduled macroeconomic news is released. Macroeconomic news dummy includes the releases of new data on the Czech producer and consumer price indexes, GDP and balance of payments. Interest rate differential, intdiff $t$, is a difference between Czech and the euro area money market rate (1YPRIBOR and 1YEURIBOR, respectively).

In case of tick-by-tick data, the impact of central bank communication and macroeconomic news on exchange rate volatility should be non-negative, as the new information they contain affects the exchange rate return. However, in case of daily data, the expected sign of these variables is not clear-cut and the existing literature documents accordingly that they may both 
increase or decrease exchange rate volatility (Jansen and de Haan, 2005, Gabriel and Pinter, 2006, Ehrmann and Fratzscher, 2007) according to whether it has a calming effect on the markets or not. Additionally, greater interest rate differential is likely to increase exchange rate volatility (Kocenda and Valachy, 2006). Larger differential may signal the lack of synchronization of business cycle and subsequently monetary policy and exchange rate is thus more likely to adjust.

Table 1: Descriptive Statistics

\begin{tabular}{lcccccc}
\hline & $s_{t}$ & comment $_{t}$ & timing $_{t}$ & minutes $_{t}$ & news $_{t}$ & intdiff $_{t}$ \\
\hline Mean & 28.99 & 0.11 & 2.32 & 0.05 & 0.21 & -0.46 \\
Median & 28.78 & 0.00 & 0.00 & 0.00 & 0.00 & -0.36 \\
Maximum & 30.56 & 1.00 & 29.00 & 1.00 & 1.00 & 0.40 \\
Minimum & 27.42 & 0.00 & 0.00 & 0.00 & 0.00 & -1.17 \\
Standard deviation & 0.83 & 0.32 & 6.69 & 0.21 & 0.41 & 0.40 \\
Skewness & 0.25 & 2.43 & 2.68 & 4.30 & 1.42 & 0.35 \\
Kurtosis & 1.70 & 6.90 & 8.57 & 19.44 & 3.00 & 2.50 \\
Jarque-Bera test & 43.30 & 864.9 & 1332 & 7676 & 178.5 & 16.43 \\
& {$[0.00]$} & {$[0.00]$} & {$[0.00]$} & {$[0.00]$} & {$[0.00]$} & {$[0.00]$} \\
Observations & 536 & 536 & 536 & 536 & 536 & 536 \\
\hline
\end{tabular}

Notes: $p$-values are reported in the brackets. Exchange rate series in levels.

Next, we present the descriptive statistics of key variables. Several issues are noteworthy. Czech central bank communication occurs on about every tenth day on average, while macroeconomic announcements are released more common (with the mean of 0.21 ). Minutes occur monthly, as the frequency of monetary policy meetings is monthly in our sample period, too (as there are 22 business days on average per month, the mean is 0.05 ). Czech interest rates were on average nearly 0.5 percentage point below the euro area during sample period. 
Chart 1 presents the frequency of central bank communication. As the monetary policy meeting is typically held on Thursday, the results indicate that the frequency of communication is much lower in the week the monetary policy meeting is held (see the frequencies on the days 1-3 in Chart 1). The communication is the most intense from 10 to 6 days before the monetary policy meeting takes place. This finding is in line with evidence on the Bank of England, European Central Bank and the U.S. Federal Reserve (see Ehrmann and Fratzscher, 2007), where communication is more common, as the meeting comes closer. On the other hand, in contrast to these central banks, we can see that the Czech central bank communication is not more frequent after the monetary policy meeting. We suppose that this reflects the fact that the CNB puts a lot of effort in explaining their interest rate decision and risk scenarios at the press conference just after the monetary policy meeting was held.

\section{Chart 1: Frequency of Central Bank Communication}

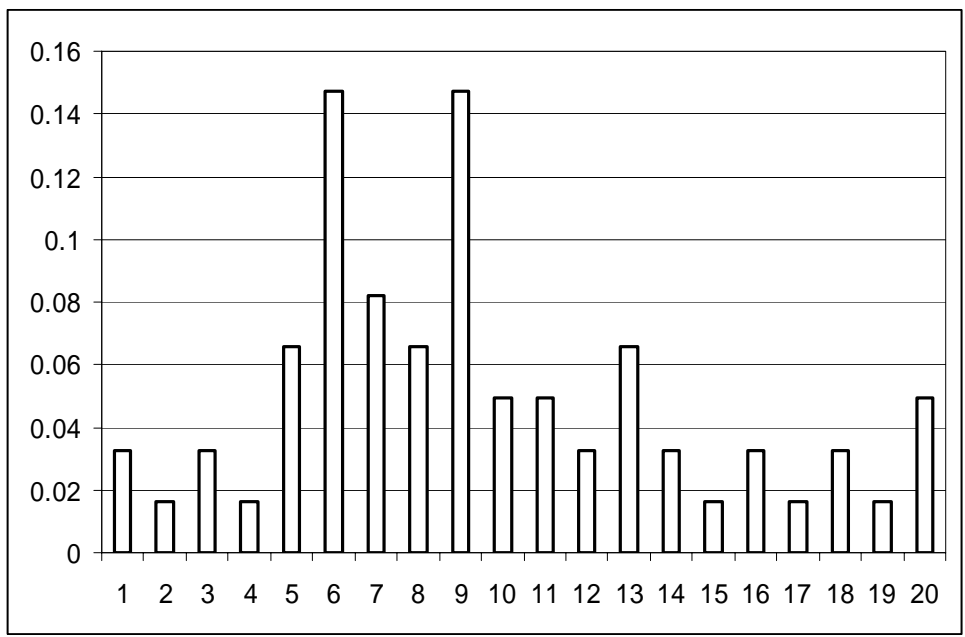

Note: Horizontal axis measure the days before monetary policy meeting. Vertical axis gives the frequency.

\section{Results}

Table 2 presents our results on the determinants of exchange rate volatility. We find that that central bank communication tends to decrease exchange rate volatility, i.e. this supports the 
view that central bank aims to decrease the noise in the financial markets (Blinder et al., 2008). The finding complies with Jansen and de Haan (2005) and Gabriel and Pinter (2006), who also find that the exchange rate volatility of EUR/USD and HUF/EUR, respectively is lower on the day, when central bank communicates its views on the economy to the public.

In addition, the results suggest that timing of central bank communication seems to matter, too. ${ }^{6}$ Similarly, Ehrmann and Fratzscher (2007) study the timing of central bank communication for the case of Bank of England, European Central Bank and the U.S. Federal Reserve Bank. Despite they define the measure of timing of central bank communication differently (primarily using various dummy variables and interacting them with the model coefficients), their results suggest that the timing of communication is informative for a whole variety of financial assets including the exchange rate.

We also find that the effect of central bank minutes is not clear, as the sign of coefficient differs across the specifications. The effect of macroeconomic news is somewhat surprising; it tends to decrease exchange rate volatility. This may reflect the fact the there is higher uncertainty in emerging markets and news is likely to have calming effect on the markets. Nevertheless, this effect is found also in some other studies in developed countries such as Kim et al. (2004), who report that DEM/USD exchange rate volatility decreases on the day the news on producer price index is released. Greater interest rate differential is found to increase exchange rate volatility (see also Kocenda and Valachy, 2006, for further evidence in the case of Czech Republic). 
Table 2: The Effect of Central Bank Communication on Exchange Rate Volatility

\begin{tabular}{|c|c|c|c|c|c|}
\hline & (1) & (2) & (3) & (4) & (5) \\
\hline \multirow[t]{2}{*}{$\mu$} & -0.000 & -0.000 & -0.000 & -0.000 & -0.000 \\
\hline & {$[0.00]$} & {$[0.00]$} & {$[0.00]$} & {$[0.00]$} & {$[0.00]$} \\
\hline \multirow[t]{2}{*}{$\gamma_{1}$} & $0.000 * * *$ & $0.000 * * *$ & $0.000 * * *$ & $0.000 * * *$ & $0.000 * * *$ \\
\hline & {$[0.00]$} & {$[0.00]$} & {$[0.00]$} & {$[0.00]$} & {$[0.00]$} \\
\hline \multirow[t]{2}{*}{$\gamma_{2}$} & $0.15^{* * *}$ & $0.15 * * *$ & 0.01 & $0.15^{*}$ & $0.15^{*}$ \\
\hline & {$[0.05]$} & {$[0.05]$} & {$[0.01]$} & {$[0.08]$} & [0.09] \\
\hline \multirow[t]{2}{*}{$\gamma_{3}$} & $0.60 * * *$ & $0.60 * * *$ & $0.95 * * *$ & $0.60 * * *$ & $0.60 * * *$ \\
\hline & {$[0.09]$} & {$[0.10]$} & {$[0.02]$} & {$[0.15]$} & {$[0.17]$} \\
\hline \multirow[t]{2}{*}{$\varphi_{1}\left(\right.$ comment $\left._{t}\right)$} & $-3.37 * * *$ & & & $-3.24 * *$ & \\
\hline & [1.19] & & & {$[1.31]$} & \\
\hline \multirow[t]{2}{*}{$\varphi_{2}\left(\right.$ timing $\left._{t}\right)$} & & $-0.15^{* *}$ & & & $-0.16^{* *}$ \\
\hline & & {$[0.07]$} & & & {$[0.06]$} \\
\hline \multirow[t]{2}{*}{$\varphi_{3}\left(\right.$ minutes $\left._{t}\right)$} & & & $4.78 * * *$ & $-4.62 * *$ & $-4.80^{*}$ \\
\hline & & & [1.21] & {$[2.33]$} & {$[2.61]$} \\
\hline \multirow[t]{2}{*}{$\rho_{1}$} & $-3.66 * * *$ & $-3.59 *$ & $-0.99 * *$ & $-3.64 * *$ & $-3.57^{*}$ \\
\hline & {$[0.91]$} & {$[2.18]$} & {$[0.40]$} & {$[1.85]$} & {$[2.06]$} \\
\hline \multirow[t]{2}{*}{$\rho_{2}$} & $1.81 * * *$ & 1.81 & $0.36^{* * *}$ & $1.86^{*}$ & 1.79 \\
\hline & {$[0.70]$} & [1.37] & {$[0.19]$} & [1.09] & [1.38] \\
\hline
\end{tabular}

\begin{tabular}{lccccc}
\hline L-B(10), RES & 12.84 & 12.77 & 13.01 & 12.85 & 12.96 \\
L-B(10), SQRES & 10.59 & 11.79 & 9.03 & 13.43 & 12.44 \\
Schwartz inf. crit. & -8.69 & -8.70 & -8.86 & -8.70 & -8.70 \\
\hline$N$ & 536 & 536 & 536 & 536 & 536
\end{tabular}

Notes: We report standard errors in parenthesis and Ljung-Box $Q$-statistics of the $10^{\text {th }}$ lag for standardized and squared residuals. $* * *, * *$, and $*$ - denotes significance at 1 percent, 5 percent, and 10 percent, respectively. The value of $\varphi_{1}, \varphi_{2}, \varphi_{3}, \rho_{1}$ and $\rho_{2}$ are multiplied by $10^{6}$. 


\section{Concluding remarks}

We analyze the importance of central bank communication, macroeconomic news and interest rate differential on exchange rate volatility in the Czech Republic using GARCH framework. Our main results are as follows. Central bank communication tends to decrease exchange rate volatility, i.e. this supports the view that central bank aims to decrease the noise in the financial markets. The timing of central bank communication seems to matter, too. Macroeconomic news is found to decrease exchange rate volatility. This may reflect the fact the there is higher uncertainty in emerging markets and news is likely to have calming effect on the markets. 


\section{References}

Blinder, A. S., Ehrmann, M., Fratzscher, M., Haan, J. D., and Jansen, D.-J. (2008). Central Bank Communication and Monetary Policy: A Survey of Theory and Evidence. Journal of Economic Literature, 46(4), 910-945.

Bollerslev, T. (1986). Generalized Autoregressive Conditional Heteroskedasticity. Journal of Econometrics, 31, 307-327.

Bulir, A. and Smidkova, K. (2007). Striving to Be "Clearly Open" and "Crystal Clear": Monetary Policy Communication of the CNB. Finance a uver - Czech Journal of Economics and Finance, 57 (11-12), 540-557.

Ehrmann, M. and Fratzscher, M. (2007). The Timing of Central Bank Communication. European Journal of Political Economy, 23 (1), 124-145.

Evans, M. D. and Lyons, R. K. (2005). Do Currency Markets Absorb News Quickly?. Journal of International Money and Finance, 24 (2), 197-217.

Gabriel, P. and Pinter, K. (2006). The Effect of the MNB's Communication on Financial Markets. MNB Working Papers 2006/9, Magyar Nemzeti Bank (The Central Bank of Hungary).

Jansen, D.-J. and De Haan, J. (2005). Talking Heads: The Effects of ECB Statements on the Euro-Dollar Exchange Rate. Journal of International Money and Finance, 24 (2), 343-361.

Kim, S.-J., McKenzie, M. D., and Faff, R. W. (2004). Macroeconomic News Announcements and the Role of Expectations: Evidence for US Bond, Stock and Foreign Exchange Markets. Journal of Multinational Financial Management, 14 (3), 217-232.

Kocenda, E. and Valachy, J. (2006). Exchange Rate Volatility and Regime Change: A Visegrad Comparison, Journal of Comparative Economics, 34(4), 727-753.

Kohn, D. L. and Sack, B. P. (2003). Central Bank Talk: Does It Matter and Why? Finance and Economics Discussion Series 2003-55, Board of Governors of the Federal Reserve System (U.S.).

Rozkrut, M., Rybinski, K., Sztaba, L., and Szwaja, R. (2007). Quest for Central Bank Communication: Does It Pay to Be "Talkative"? European Journal of Political Economy, 23, 176-206. 
${ }^{1}$ See also Kohn and Sack (2003) on why and how the central bank communication matters for financial markets.

${ }^{2}$ Rozkrut et al. (2007) study the impact of central bank communication on the interest rate in a group of Central European countries. Anecdotal evidence on monetary policy communication of the Czech National Bank is provided by Bulir and Smidkova (2007).

${ }^{3}$ Note that we also estimated GARCH model with higher lags, but failed to find them significant. In addition, as bad news are sometimes found to matter more in financial markets, we also examined asymmetric GARCH models such as threshold autoregressive conditional heteroscedasticity - TARCH - model or exponential generalized autoregressive conditional heteroscedasticity - EGARCH, but did not find any asymmetry. These results are available upon request. See Bollerslev (1986) on GARCH modelling.

${ }^{4}$ Eq. (1) is defined in levels, as we can't reject the null hypothesis of unit root in the level of exchange rate.

${ }^{5}$ For this reason, we assess whether the communication of governor matters more than the communication of other members. We construct two dummy variables for the communication of governor and other Board members. Controlling for other factors, we find the coefficient on governor's communication larger than the coefficient on other member's communication, but the difference between the respective coefficients is not statistically significant.

${ }^{6}$ The correlation coefficient between timing and comments is 0.96 and therefore, we do not include these two variables together in the regression because of multicollinearity. 